\title{
Posttraumatická perforace pravé srdeční síně stimulační elektrodou
}

\author{
Pavel Mikulenčák, Čestmír Číhalík, Josef Novotný*, Petr Neužil** \\ Interní klinika IPVZ, Krajská nemocnice Tomáš Bati, a.s., Zlín, *Vojenská nemocnice Olomouc, **Nemocnice Na Homolce, Praha, Česká \\ republika
}

Pacientka ve věku 44 let, s trvalou dvoudutinovou kardiostimulací v režimu DDD pro síňokomorovou blokádu (AVB) III. stupně od listopadu 2008, byla v únoru 2009 přijata $\mathrm{k}$ rehospitalizaci na naši kliniku pro progredující dušnost, nevýkonnost, prekolapsové stavy.

Při přijetí udávala, že obtížím předcházel pád na náledí na záda, následně pocitovala bodavou bolest $\mathrm{v}$ prekordiu. Vstupní fyzikální a laboratorní vyšetření neukázala patologický nález, pacientka byla bez známek traumatu, normotenzní.
Na příjmovém EKG byl přítomen stimulovaný komorový rytmus o frekvenci 60/min, porucha sensingu (snímání) vln $\mathrm{P}$ a síňové stimulace (obrázek 1 ). Stav se nedařilo řešit ani programací kardiostimulátoru. Byl patrný výrazný nárůst stimulačního prahu a odporu na síňové elektrodě.

Pacientce byla provedena skiaskopie, kde byla patrna velmi pravděpodobná perforace síňového myokardu elektrodou, jejíž distální konec přesahoval konturu srdečního stínu (obrázek 2).

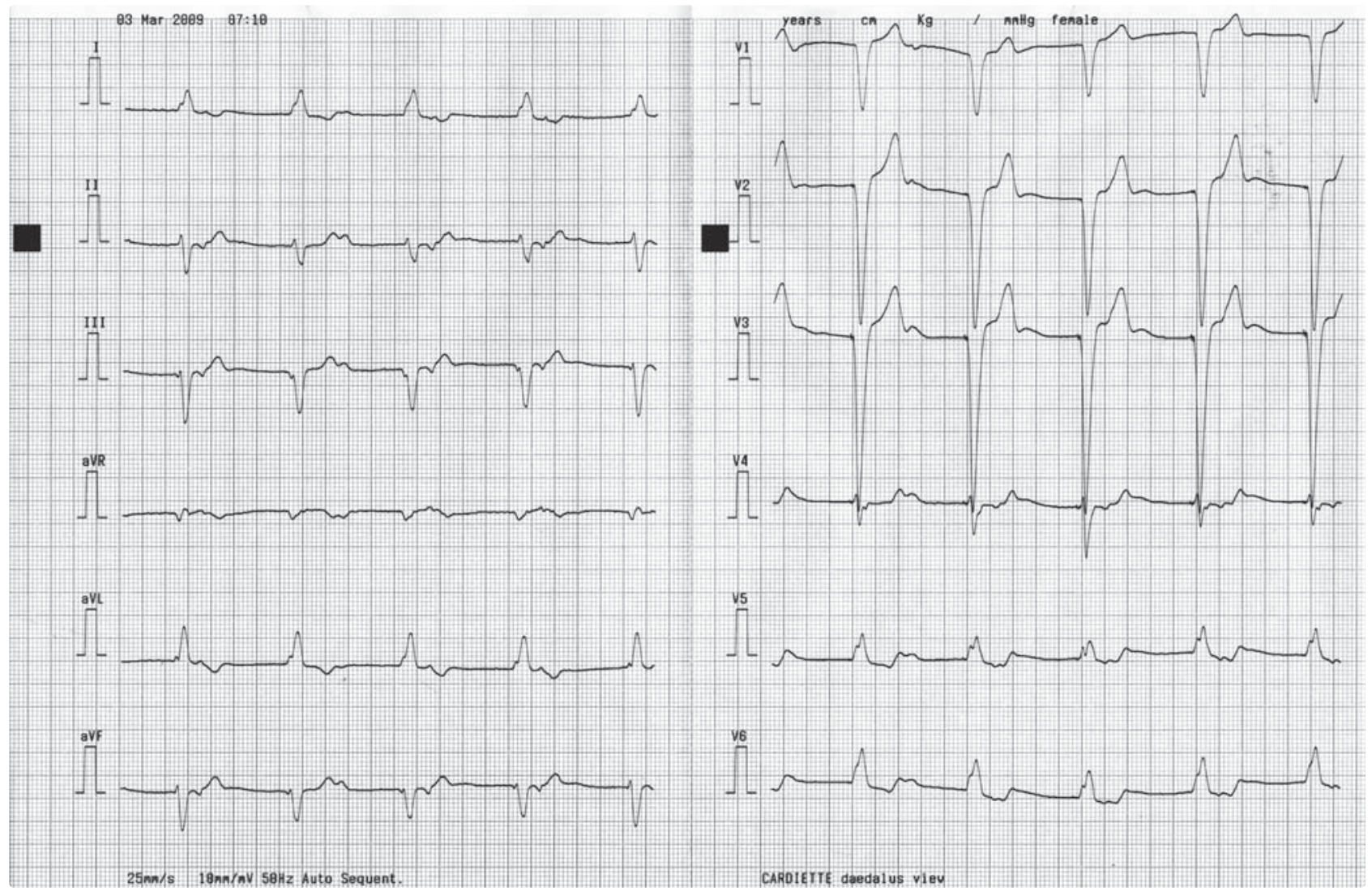

Obrázek 1 EKG se stimulovaným komorovým rytmem, poruchou sensingu vln P

Adresa: Interní klinika IPVZ, Krajská nemocnice Tomáš Bati, a.s., Zlín, Havlíčkovo nábřeží 600, 76000 Zlín, Česká republika, e-mail: pmikulencak@seznam.cz 
Echokardiograficky byla prrítomna pouze lehká regurgitace na AV ústích, perikard bez výpotku.

$\mathrm{Na}$ základě skiaskopie bylo indikováno spirální CT vyšetření srdce s doplněním rekonstrukcí. Bylo zřejmé, že síňová elektroda se stáčí kraniálně, konečná část v délce přibližně $12 \mathrm{~mm}$ přesahovala okraj pravé síně (obrázky 3 a 4). Hrot elektrody byl uložen asi 3,5 mm od horní duté žíly a $6 \mathrm{~mm}$ laterálně od ascendentní aorty (obrázek 5).

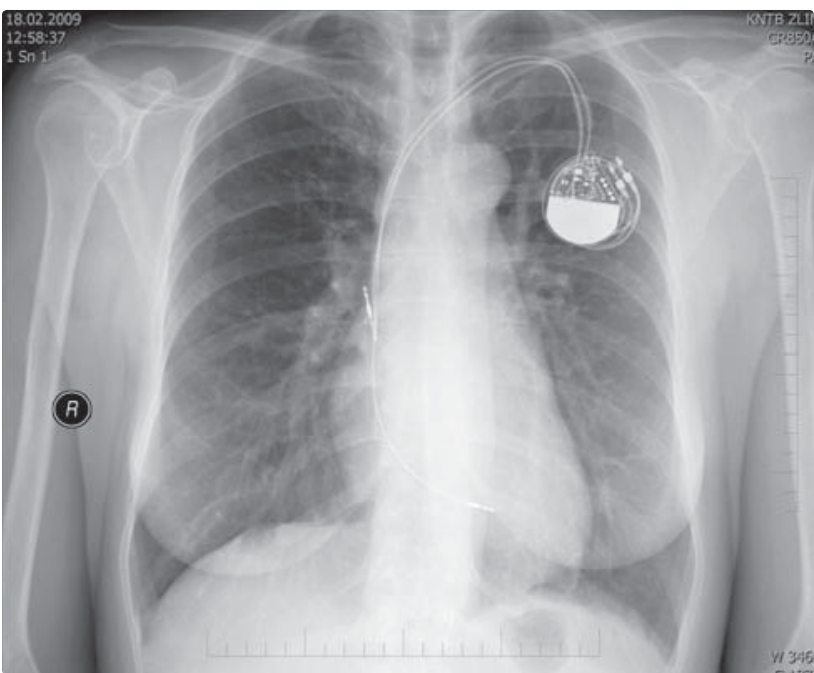

Obrázek 2 RTG snímek hrudníku se síňovou elektrodou mimo konturu myokardu

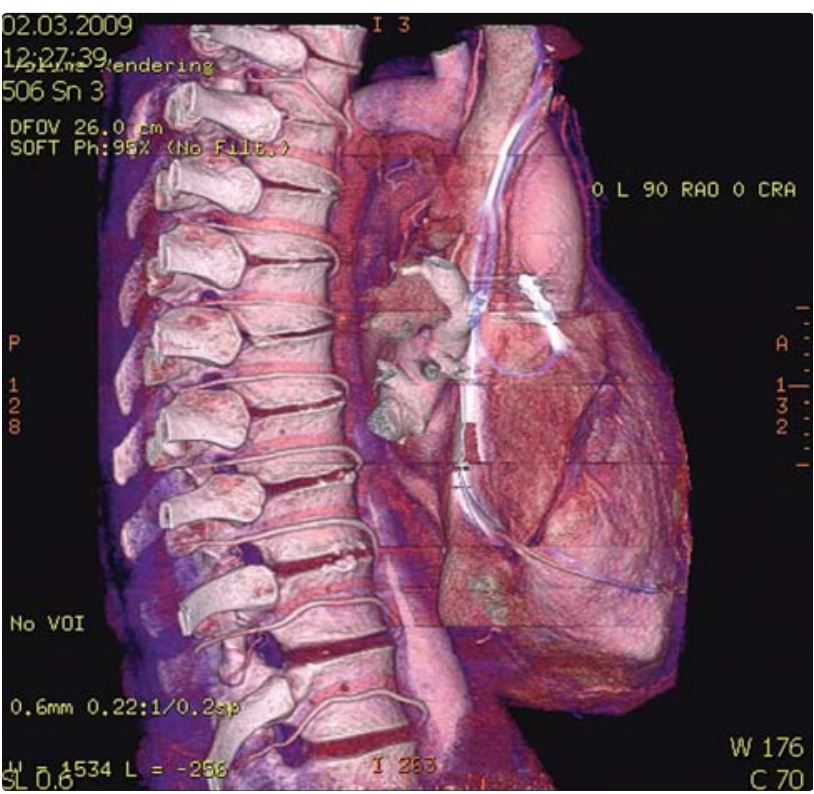

Obrázek 3 Rekonstrukce CT vyšetření srdce s penetrovanou síňovou elektrodou
Za kontroly intrakardiální echokardiografí́ byla provedena nekomplikovaná extrakce obou elektrod s následnou kontralaterální reimplantací kardiostimulátoru.

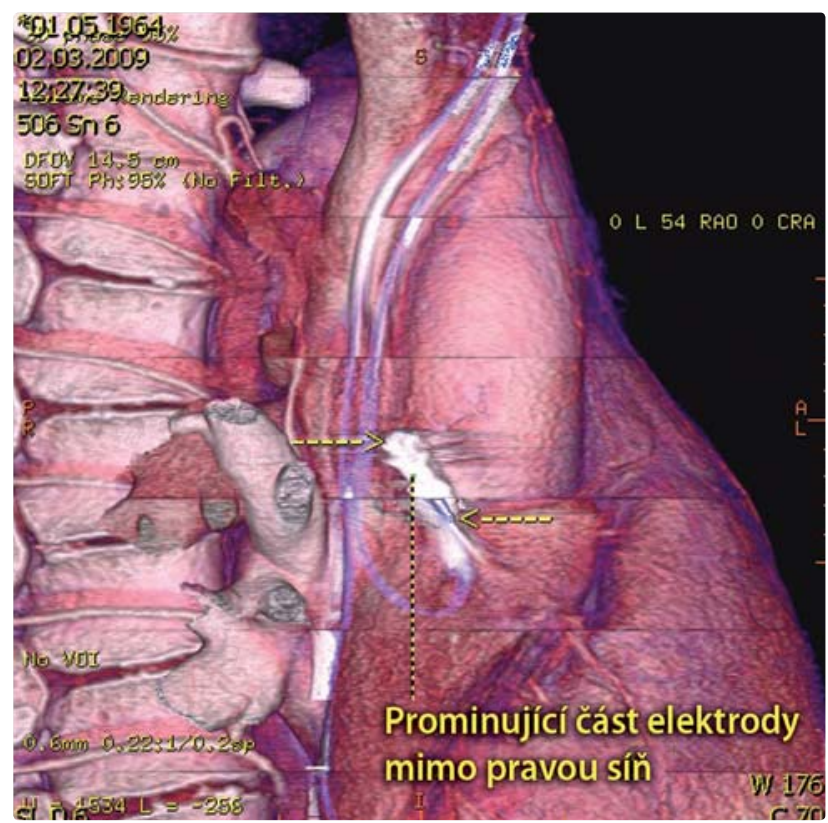

Obrázek 4 Detail prominující části elektrody

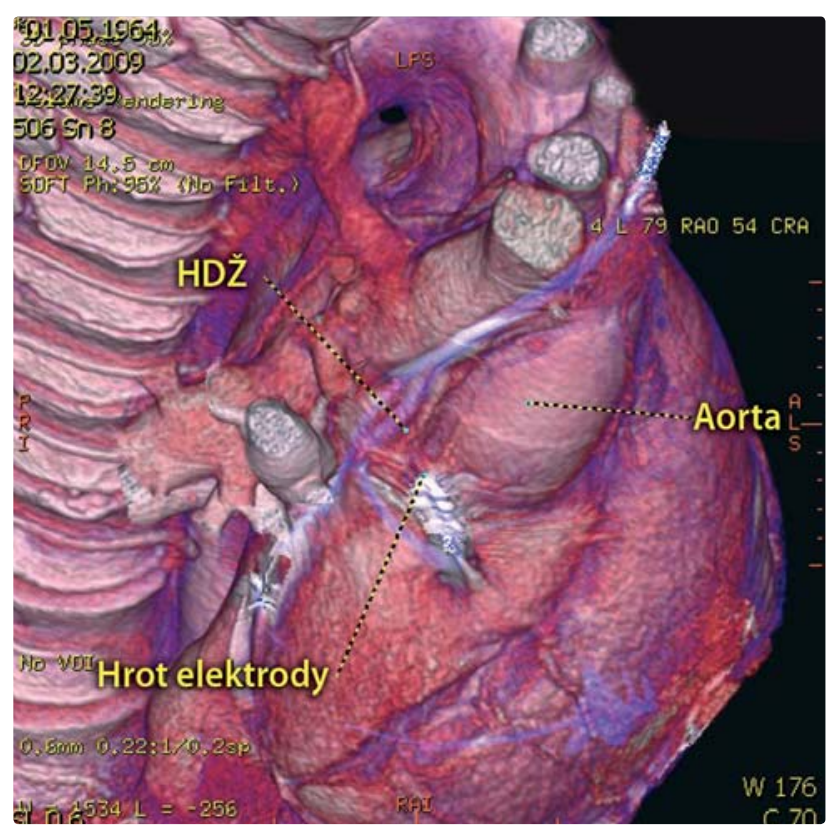

Obrázek 5 Anatomický vztah prominující části elektrody k horní duté žíle a aortě

HDŽ - horní dutá žlla 